\title{
Expression of EphA1 in gastric carcinomas is associated with metastasis and survival
}

\author{
JIANDONG WANG ${ }^{1,2}$, YINGCHUN DONG ${ }^{1}$, XULIN WANG $^{3}$, HENGHUI MA $^{1}$, ZHEN SHENG $^{1}$, \\ GULI LI ${ }^{3}$, GUANGMING LU² ${ }^{2}$ HARUHIKO SUGIMURA ${ }^{4}$ and XIAOJUN ZHOU ${ }^{1}$

\begin{abstract}
Departments of ${ }^{1}$ Pathology, ${ }^{2}$ Radiology and ${ }^{3}$ Surgery, Nanjing Jinling Hospital, Nanjing University School of Medicine, Nanjing 210002, P.R. China; ${ }^{4}$ Department of Pathology of Hamamatsu University School of Medicine,
\end{abstract} \\ 1-20-1, Handayama, Hamamatsu 431-3192, Japan
}

Received April 29, 2010; Accepted June 17, 2010

DOI: $10.3892 /$ or_00001020

\begin{abstract}
Receptor tyrosine kinases of the Eph subfamily are involved in the development and the carcinogenesis of certain cancers. In this study we investigated expression of EphA1 in gastric carcinomas, and analyzed associations between EphA1 expression and clinicopathological parameters to investigate the role of EphA1 in gastric carcinoma. The level of EphA1 transcript expression in gastric carcinoma tissue and corresponding normal tissue was determined by quantitative real-time reverse transcriptase polymerase chain reaction (RT-PCR). The status of the $\mathrm{CpG}$ island associated with the promoter region of EphA1 was assessed by methylation-specific PCR (MSP), and EphA1 protein expression of was examined by immunohistochemical staining (IHC). Down-regulation of EphA1 transcripts was detected in $34 \%$ of the cases, up-regulation in $25 \%$ of the cases, and no difference in expression in $41 \%$ of the cases. The EphA1 transcript expression level was associated with tumor size $(\mathrm{P}=0.05)$, stage $(\mathrm{P}=0.001)$, and lymph node metastasis $(\mathrm{P}=0.011)$. Methylated EphA1 DNA was detected in most of the carcinomas with EphA1 down-regulation that were examined. EphA1 protein expression was associated with depth of wall invasion $(\mathrm{P}=0.069)$, stage $(\mathrm{P}<0.001)$, and lymph node metastasis $(\mathrm{P}=0.018)$. The survival analysis showed that patients whose tumor exhibited EphA1 upregulation had a poorer outcome than those whose tumor exhibited down-regulation $(\mathrm{P}=0.005)$ or no difference in expression $(\mathrm{P}=0.003)$. EphA1 may have roles in invasion and metastasis by gastric carcinoma. The EphA1 expression level is a potential prognostic marker in gastric carcinoma, and the
\end{abstract}

Correspondence to: Dr Xiaojun Zhou, Department of Pathology, Nanjing Jinling Hospital, Nanjing University School of Medicine, Nanjing 210002, P.R. China

E-mail: nanjing_81@yahoo.com

Dr Haruhiko Sugimura, Department of Pathology of Hamamatsu University School of Medicine, 1-20-1, Handayama, Hamamatsu 431-3192, Japan

E-mail: hsugimur@hama-med.ac.jp

Key words: EphA1, gastric carcinoma, metastasis, survival
EphA1 gene may provide a novel target of therapy for gastric carcinoma.

\section{Introduction}

Gastric cancer is very common worldwide, especially in Eastern Asia, the Andean regions of South America, and Eastern Europe. Although a steady decline in incidence and mortality rates has been observed, the absolute number of new cases has been increasing annually, and gastric carcinoma is now the second leading cause of cancer deaths worldwide (1). Epidemiological studies have shown that Helicobacter-pylori infection is an important factor in the carcinogenesis of gastric carcinoma, and other factors, including diet, alcohol consumption, and tobacco have been shown to be associated with the risk of gastric carcinoma and its precursor lesions. Accumulating evidence has indicated that gastric carcinoma is also associated with various genetic and epigenetic alterations of oncogenes, tumor suppressor genes, DNA repair genes, cell cycle regulators, and cell adhesion molecules (2-9). However, the genetic and epigenetic changes associated with the development, progression, and prognosis of gastric carcinoma are still poorly understood.

Receptor tyrosine kinases of the Eph family and Ephrin ligands play important roles in vascular development, tissueborder formation, cell migration, axon guidance, and angiogenesis, and abnormal expression of Eph receptor tyrosine kinases in cancers is related to malignant transformation, tumor metastasis, tumor differentiation, and outcome. EphAl, the first member of the Eph receptor tyrosine kinase family ever discovered, was isolated from erythropoietin-producing hepatocellular carcinoma cell lines and is located on chromosome $7 q 34$ (10). It is widely expressed in normal tissue including lung, small intestinal, kidney, bladder, thymus, and colon tissue (11). The level of EphAl expression in human cancers is variable, with overexpression of EphAl having been observed in certain types of tumors, including ovarian carcinoma (12), and squamous cell carcinoma of the head and neck (13), and reduced expression detected in prostate cancer cell lines (14), breast carcinoma cell lines (15), and basal cell carcinomas and squamous cell carcinomas of the skin (16). However, the role of EphA1 in the carcinogenesis of digestive tract tumors is unknown. We previously reported 
Table I. Characteristics of 145 patients with gastric carcinoma.

\begin{tabular}{|c|c|c|c|}
\hline Variable & $\begin{array}{c}\text { mRNA } \\
\text { and protein }\end{array}$ & $\begin{array}{c}\text { Protein and } \\
\text { follow-up }\end{array}$ & Total no. \\
\hline Case no. & 56 & 89 & 145 \\
\hline \multicolumn{4}{|l|}{ Gender } \\
\hline Male & 41 & 64 & 105 \\
\hline Female & 15 & 25 & 40 \\
\hline \multicolumn{4}{|l|}{ Age (years) } \\
\hline$\leq 50$ & 9 & 23 & 32 \\
\hline$>50$ & 47 & 66 & 113 \\
\hline \multicolumn{4}{|l|}{ Tumor differentiation } \\
\hline Moderate & 26 & 33 & 59 \\
\hline Poor & 30 & 56 & 86 \\
\hline \multicolumn{4}{|l|}{ Tumor size (cm) } \\
\hline$<5$ & 25 & 47 & 72 \\
\hline$\geq 5$ & 31 & 42 & 73 \\
\hline \multicolumn{4}{|l|}{ Depth of wall invasion } \\
\hline Mucosa, submucosa & 2 & 9 & 11 \\
\hline Muscularis propria & 13 & 13 & 26 \\
\hline Subserosa, serosa & 41 & 67 & 108 \\
\hline \multicolumn{4}{|l|}{ Stage } \\
\hline I + II & 22 & 33 & 55 \\
\hline III + IV & 34 & 56 & 90 \\
\hline \multicolumn{4}{|l|}{ Microscopic subtypes } \\
\hline Intestinal & 38 & 52 & 90 \\
\hline Diffuse & 15 & 36 & 51 \\
\hline Atypical & 3 & 1 & 4 \\
\hline \multicolumn{4}{|l|}{ Lymph node metastasis } \\
\hline Present & 38 & 60 & 98 \\
\hline Absent & 18 & 29 & 47 \\
\hline
\end{tabular}

finding correlations between down-regulation of EphA1 in colorectal carcinomas and invasion and metastasis, and that reduced EphA1 expression is associated with poor overall survival (17), while another study demonstrated that epigenetic silencing of EphA1 expression in colorectal cancer is correlated with poor survival (18). In the present study we evaluated expression of EphA1 in a set of gastric carcinomas and analyzed its association with clinicopathological parameters and survival.

\section{Materials and methods}

Gastric carcinoma tissue specimens. All of the tissue samples in this study were collected from 145 patients with gastric carcinoma who underwent surgery at the Nanjing Jinling Hospital. In 56 gastric carcinomas fresh tissue and adjacent normal mucosa were obtained from surgical specimens resected during operations performed between 2005 and 2006, and the fresh tissue samples were frozen in liquid nitrogen immediately after the resection and stored at $-80^{\circ} \mathrm{C}$ for preparation of the total RNA. The other 89 tissue samples were from formalin-fixed and paraffin-embedded tissue specimens with follow-up data obtained from the Pathology Department, and the specimens were obtained during surgery performed between 2002 and 2006 at Nanjing Jinling Hospital. This study is a part of a gastric carcinoma project approved by the Research Ethics Board of the Nanjing Jinling Hospital, Nanjing University School of Medicine and Hamamatsu University School of Medicine. The tissue specimens examined in our study were diagnosed pathologically. The clinicopathological features of the 145 gastric carcinoma patients are shown in Table I.

Total RNA extraction and quantitative real-time $R T-P C R$. Total RNA was extracted from tumor tissue and adjacent normal mucosa by homogenizing tissue in TRIzol reagent (Invitrogen, CA, USA) according to the manufacturer's protocol. For reverse transcription, a $2-\mu \mathrm{g}$ sample of total RNA was used for cDNA synthesis with oligo (dT) primers and M-MLV reverse transcriptase (Promega, Madison, WI, USA) in a final volume of $20 \mu 1$. Expression of EphA1 transcripts in the carcinoma samples was detected by subjecting the cDNAs to quantitative real-time reverse transcriptase-polymerase chain reaction (RT-PCR). The reactions were performed in triplicate. The sense and antisense primers and TaqMan probe for EphA1 were designed according to the mRNA sequence (GenBank accession number NM_005232). Amplification of PCR fragments spanning different exons was used to prevent contamination by genomic DNA. The sense primer used was 5'-ATCTTTG GGCTGCTGCTTGG-3', and the anti-sense primer was 5'-G CTTGTCCTCTCGATCCACATC-3'. The PCR products were $127 \mathrm{bp}$ long. The TaqMan probe used was 5'-(FAM) CGGTCACGCTGCCTCTGCTGCC (Eclipse)-3'. The housekeeping gene glyceraldehyde-3-phosphate dehydrogenase (GAPDH) was used as an internal control (GenBank accession number: NM_002046). The sense primer used was 5'-CCAGGTGGTCTCCTCTGACTT-3', and the anti-sense primer was 5'-GTTGCTGTAGCCAAATTCGTTGT-3'. The PCR products were $130 \mathrm{bp}$ long. The probe used was 5'(FAM) AACAGCGACACCCACTCCTCCACC (Eclipse)-3'. The EphAl mRNA expression values were normalized to $G A P D H$ expression. The primers and probes for EphAl and GAPDH were synthesized by Takara Biotechnology, Inc., (Dalian, China). The reaction mixture consisted of $3.0 \mu 110 \mathrm{X}$ buffer, $3.0 \mu 12.0 \mu \mathrm{mol} / 1$ deoxy-ribonucleoside triphosphates (dNTPs, Invitrogen), $3.0 \mu 13 \mu \mathrm{mol} / 1$ sense primer, $3.0 \mu 1$ $3.0 \mu \mathrm{mol} / 1$ antisense primer, $1.0 \mu 13 \mu \mathrm{mol} / 1$ fluorescence probe, $0.20 \mu 15 \mathrm{U} / \mu 1$ Takara ExTaq Hotstart Taq (Takara Biotechnology), $0.6 \mu \mathrm{M}$ 5-carboxy-X-rhodamine (ROX) reference dye (Invitrogen), $2.0 \mu 1 \mathrm{cDNA}$ template, and distilled water to a total volume of $30 \mu \mathrm{l}$. The PCR cycling conditions were: $2 \mathrm{~min}$ at $95^{\circ} \mathrm{C}$ followed by 40 amplification cycles of denaturation at $94^{\circ} \mathrm{C}$ for $30 \mathrm{sec}$, annealing at $59^{\circ} \mathrm{C}$ for $30 \mathrm{sec}$, and elongation at $72^{\circ} \mathrm{C}$ for $1 \mathrm{~min}$.

Methylation-specific PCR (MSP). Genomic DNA was modified by sodium bisulfite as we previously described (19). Primers were designed by using the MethPrimer software program on the Internet (http://www.urogene.org/ 
methprimer/) to discriminate between methylated and unmethylated alleles following sodium bisulfite treatment. Two-microliter aliquots were amplified in a $30-\mu 1$ reaction mixture consisting of $1 \mathrm{X}$ buffer $(10 \mathrm{mM}$ Tris- $\mathrm{HCl}, 2.0 \mathrm{mM}$ $\left.\mathrm{MgCl}_{2}, 50 \mathrm{mM} \mathrm{KCl}, \mathrm{pH} 8.3\right), 1 \mathrm{U}$ Takara ExTaq Hotstartaq, $260 \mu \mathrm{M}$ dNTPs, and $0.3 \mu \mathrm{M}$ of the primer sets. The PCR reaction conditions were $2 \mathrm{~min}$ at $95^{\circ} \mathrm{C}$, then 35 cycles of $94^{\circ} \mathrm{C}$ for $30 \mathrm{sec}, 55^{\circ} \mathrm{C}$ for $30 \mathrm{sec}$, and $72^{\circ} \mathrm{C}$ for $1 \mathrm{~min}$, and finally $10 \mathrm{~min}$ at $72^{\circ} \mathrm{C}$. The methylation-specific primers were 5'-ATTCGGGTTATTGTTTTAGGTTTC-3' (forward) and 5'-GAAAATCGATACCTTCCTTAACG-3' (reverse). The PCR products were $129 \mathrm{bp}$. Unmethylation-specific primers were 5'-ATTTGGGTTATTGTTTTAGGTTTTG-3' (forward) and 5'-ACAAAAATCAATACCTTCCTTAA CAC-3' (reverse). Primer sets for detection of methylated and unmethylated DNA were located at the same sites in the genomic sequence (forward primer at -35 to -12 from the translation start site; reverse primer at 71-93). The PCR products were $131 \mathrm{bp}$ long. The PCR products were separated on $8 \%$ non-denaturing polyacrylamide gel, and they were stained with ethidium-bromide.

Immunohistochemical staining (IHC). Sections from the surgical specimens fixed in $10 \%$ formalin and embedded in paraffin were used for immunohistochemical staining by the standard method. Briefly, each $4-\mu \mathrm{m}$ tissue section was deparaffinized and rehydrated. After rehydration through a graded ethanol series, the sections were autoclaved in $10 \mathrm{mM}$ citrate buffer $\left(\mathrm{pH} \mathrm{6.0)}\right.$ ) at $120^{\circ} \mathrm{C}$ for $2 \mathrm{~min}$ for antigen retrieval, then cooled to $30^{\circ} \mathrm{C}$ and washed with phosphatebuffered saline (PBS, $\mathrm{pH} 7.3$ ). After blocking non-specific sites had been blocked with $10 \%$ normal calf serum in phosphate-buffered saline for $10 \mathrm{~min}$, the sections were incubated at $4^{\circ} \mathrm{C}$ overnight with an anti-EphA1 polyclonal antibody (Abgent, San Diego, CA, USA) at a 1:100 dilution in Antibody Diluent (Zymed, Invitrogen, USA), then washed with PBS. Next the sections were incubated with secondary antibody (Dako, UK) for $30 \mathrm{~min}$ at room temperature. Color development was performed with 3,3'-diaminobenzidine (DAB). Nuclei were lightly counterstained with hematoxylin. The adsorption test was performed by incubating the antigenic peptide used to generate the antibody. Two pathologists independently assessed the immunostained slides, and any differences in the staining scores were resolved by consensus. Staining intensity was scored using the following scale: negative, 0 ; weak, 1; moderate, 2; and strong, 3. Staining was semiquantitatively scored according to the proportion of cells that stained by using the following scale: 0 , no cells stained; $1,<10 \%$ stained; $2,10-50 \%$ stained; and $3,>50 \%$ of the cells stained. The scores for expression and proportion of positive cells that stained were added. EphA1 expression was assessed by comparing the scores of tumor tissues and adjacent normal mucosa tissues.

Statistical analysis. The statistical significance of intergroup differences was evaluated by a $\chi^{2}$ test. All statistical analyses were performed by using SPSS software program (SPSS, Chicago, IL). Kaplan-Meier survival analysis was used to examine the relationship between categorical groups and survival in the univariate analysis. A two-sided P-value of

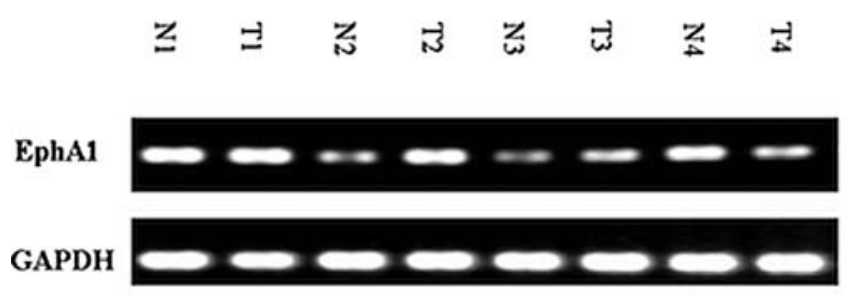

Figure 1. EphA1 transcript expression was detected by RT-PCR in gastric cancer tumor tissue $(\mathrm{T})$ and corresponding normal mucosa $(\mathrm{N})$.

$<0.05$ was considered statistically significant in all of the statistical tests.

\section{Results}

Differences in expression of EphAl transcripts by gastric carcinomas. Expression of EphA1 transcripts was detected by real-time PCR in all 56 gastric carcinoma specimens that contained paired normal mucosa and tumor. There was marked interspecimen variability in the levels of EphA1 expression in the gastric cancer specimens (Fig. 1). The specimens were divided into three groups according to the ratio of the EphA1 expression level in the normal mucosa to the level in the tumor tissue: a group in which the ratio of the level of EphA1 expression in the normal mucosa to the level in the tumor tissue was $>2$ (normal mucosa, tumor ratio $>2$, $\mathrm{N} / \mathrm{T}>2$; group A); a group in which the ratio was $<0.5$ (normal mucosa, tumor ratio $<0.5, \mathrm{~N} / \mathrm{T}<0.5$; group $\mathrm{B}$ ); and a group in which the ratio was between 0.5 and 2 ; group $\mathrm{C}$ (Table II). Down-regulation of EphA1 (normal mucosa, tumor ratio $>2, \mathrm{~N} / \mathrm{T}>2$ ) was observed in 19 out of the 56 (34\%) gastric carcinoma specimens; overexpression of EphA1 (normal mucosa, tumor ratio $<0.5, \mathrm{~N} / \mathrm{T}<0.5$ ) was observed in 14 out of the $56(25 \%)$ gastric carcinoma specimens; and no difference in expression (normal mucosa, tumor ratio between 0.5 and 2, N/T 0.5-2) was observed in 23 of the 56 (41\%) specimen.

Associations between EphAl transcript expression and clinicopathological parameters. The associations of the EphA1 transcript expression and various clinical variables are shown in Table II. There was a significant correlation between EphA1 transcript expression and tumor size $(\mathrm{P}=0.05)$, tumor stage $(\mathrm{P}=0.001)$, and lymph node metastasis $(\mathrm{P}=0.011)$. No significant correlations were found between EphA1 transcript expression and gender, age, differentiation, or microscopic subtype.

Methylated EphAl DNA was detected in most specimens with down-regulation of EphAl expression. The methylation status of the $5^{\prime} \mathrm{CpG}$ island around the translation start site was assessed by the methylation-specific PCR (MSP) (Fig. 2). Evidence of hypermethylation of the ${ }^{\prime} \mathrm{CpG}$ island was found in some of gastric carcinoma specimens. Methylated EphA1 DNA was detected in $16(42 \%)$ of 38 gastric carcinoma samples, and the 16 samples were from $12(80 \%)$ of 15 tumor specimens in which EphA1 was down-regulated, and from $4(17 \%)$ of 23 tumor specimens in which the 
Table II. Relation between expression of EphA1 transcript and protein and clinicopathological parameters of gastric carcinomas.

\begin{tabular}{|c|c|c|c|c|c|c|c|c|}
\hline \multirow[b]{2}{*}{ Variable } & \multicolumn{3}{|c|}{ EphA1 transcript expression } & \multirow[b]{2}{*}{ P-value } & \multicolumn{3}{|c|}{ EphA1 protein expression } & \multirow[b]{2}{*}{ P-value } \\
\hline & $\mathrm{N} / \mathrm{T}>2$ & $\mathrm{~N} / \mathrm{T} 0.5-2$ & $\mathrm{~N} / \mathrm{T}<0.5$ & & $\begin{array}{l}\text { Down- } \\
\text { regulation }\end{array}$ & $\begin{array}{c}\text { No } \\
\text { change }\end{array}$ & $\begin{array}{l}\text { Up- } \\
\text { regulation }\end{array}$ & \\
\hline Case no. & 19 & 23 & 14 & & 80 & 26 & 39 & \\
\hline \multicolumn{9}{|l|}{ Gender } \\
\hline Male & 13 & 19 & 9 & 0.401 & 54 & 20 & 31 & 0.331 \\
\hline Female & 6 & 4 & 5 & & 26 & 6 & 8 & \\
\hline \multicolumn{9}{|l|}{ Age (years) } \\
\hline$\leq 50$ & 2 & 2 & 5 & 0.068 & 17 & 5 & 10 & 0.802 \\
\hline$>50$ & 17 & 21 & 9 & & 63 & 21 & 29 & \\
\hline \multicolumn{9}{|l|}{ Differentiation } \\
\hline Moderately differentiated & 9 & 13 & 4 & 0.254 & 29 & 13 & 17 & 0.422 \\
\hline Poorly differentiated & 10 & 10 & 10 & & 51 & 13 & 22 & \\
\hline \multicolumn{9}{|l|}{ Tumor size (cm) } \\
\hline$<5$ & 12 & 6 & 7 & 0.05 & 40 & 16 & 16 & 0.268 \\
\hline$\geq 5$ & 7 & 17 & 7 & & 40 & 10 & 23 & \\
\hline \multicolumn{9}{|l|}{ Depth of wall invasion } \\
\hline Mucosa, submucosa & 2 & 0 & 0 & & 7 & 4 & 0 & 0.069 \\
\hline Muscularis propria & 6 & 5 & 2 & 0.373 & 17 & 5 & 4 & \\
\hline Subserosa, serosa & 11 & 18 & 12 & & 56 & 17 & 35 & \\
\hline \multicolumn{9}{|l|}{ Stage } \\
\hline $\mathrm{I}+\mathrm{II}$ & 13 & 8 & 1 & 0.001 & 41 & 11 & 3 & $<0.001$ \\
\hline $\mathrm{III}+\mathrm{IV}$ & 6 & 15 & 13 & & 39 & 15 & 36 & \\
\hline \multicolumn{9}{|l|}{ Microscopic subtypes } \\
\hline Intestinal & 14 & 14 & 10 & 0.789 & 50 & 17 & 23 & 0.964 \\
\hline Diffuse & 5 & 7 & 3 & & 28 & 9 & 14 & \\
\hline Other & 0 & 2 & 1 & & 2 & 0 & 2 & \\
\hline \multicolumn{9}{|l|}{ Lymph node metastasis } \\
\hline Present & 8 & 18 & 12 & 0.011 & 47 & 18 & 33 & 0.018 \\
\hline Absent & 11 & 5 & 2 & & 33 & 8 & 6 & \\
\hline
\end{tabular}

Table III. The relation between expression of EphA1mRNA and the hypermethylation of DNA in gastric tumor tissues.

\begin{tabular}{lcccc}
\hline mRNA expression & Case no. & Hypermethylation (+) & Hypermethylation (-) & P-value \\
\hline Down-regulation & 15 & 12 & 3 & 0.001 \\
No change & 18 & 3 & 15 & \\
Up-regulation & 5 & 1 & 4 & \\
\hline Total number & 38 & 16 & 22 \\
\hline
\end{tabular}

EphA1 was not down-regulated. Hypermethylation status was significantly associated with the level of EphA1 transcript expression $(\mathrm{P}=0.001)$. It is noteworthy that methylated
DNA was also detected in one tumor sample in which the expression of EphA1 was overexpressed (Table III). Analysis of the relations between hypermethylation and clinicopatho- 


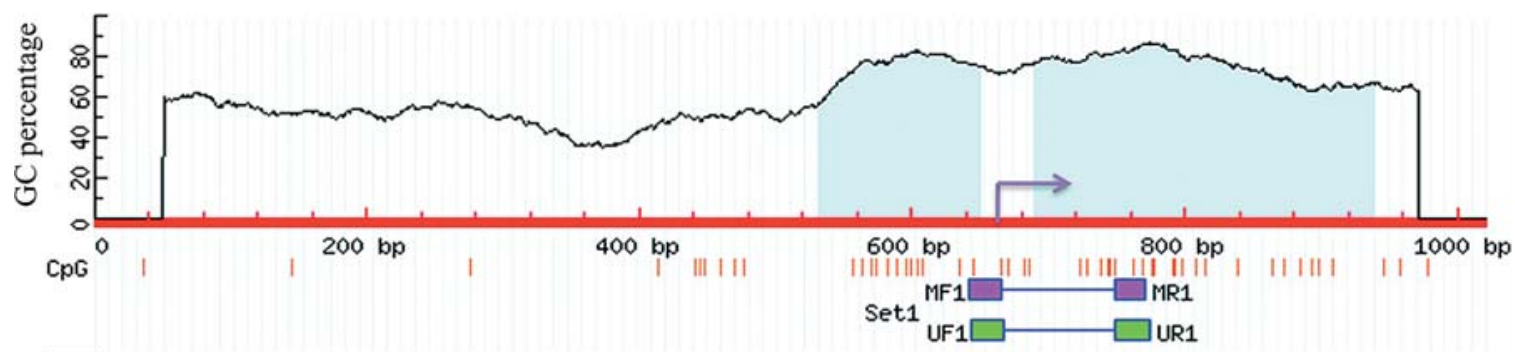

A

\section{9n $9 t \quad 10 n$ 10t 15n 15t 16n 16t 17n 17t}

\section{$\mathbf{M}$}

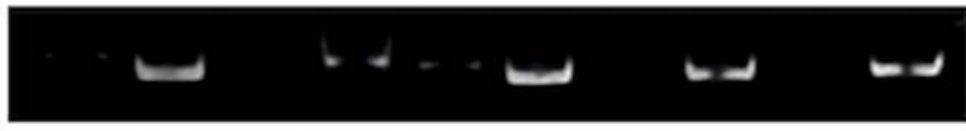

$\mathbf{U}$

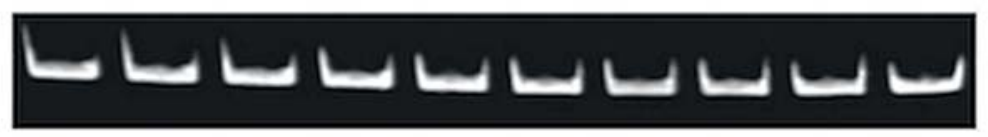

B

Figure 2. Hypermethylation of the CpG island of EphA1 was investigated by MSP. (A) Schematic diagram showing the promoter-associated CpG island in EphA1 and the location of the PCR primer sets for specific detection of methylated and unmethylated EphA1 DNA. The arrow points to the translation start site of EphA1. (B) Methylated and unmethylated EphA1 DNA were detected in gastric carcinoma tissue and normal mucosa.

logical parameters revealed significant associations between EphA1 methylation status and both tumor differentiation and size (Table IV).

Expression of EphA1 protein in normal gastric mucosa cells and gastric carcinoma cells. A polyclonal EphA1 antibody was used to immunohistochemically stain 145 formalinfixed paraffin-embedded specimens (Fig. 3). EphA1 protein expression varied between gastric cancer cells and adjacent normal mucosa cells, and heterogeneous staining was observed. EphA1 immunoreactivity was observed in the cytoplasm, the golgiosome, or both. Down-regulation of EphA1 protein was observed in $80(55 \%)$ of the 145 tumor specimens, overexpression of EphA1 protein in 39 (27\%) out of the 145 tumor specimens, and no difference in 26 $(18 \%)$ of the 145 tumor specimens (Table II).

Associations between EphAl protein expression and the clinicopathological parameters. The associations between the EphA1 protein expression and the clinicopathological characteristics are shown in Table II. EphA1 protein was significantly overexpressed in tumors in the patients with advanced stage $(\mathrm{P}<0.001)$ and with lymph node metastasis $(\mathrm{P}=0.018)$. Overexpression of EphA1 protein was associated with depth of wall invasion $(\mathrm{P}=0.069)$. The EphA1 protein expression was not associated with any of the other clinicopathological characteristics.

Overexpression EphAl protein was associated with poor survival of gastric carcinoma patients. Gastric carcinoma patients who underwent surgery at Nanjing Jinling Hospital between March 2002 and March 2006 were followed up and data for 87 patients are available. The follow-up period was 4-63 months, and the median follow-up period was 24 months. Paraffin tissue samples were collected and immunohistochemically stained with the specific EphA1 antibody, and we investigated associations between EphA1 protein expression and clinical outcome. The Kaplan-Meier survival analysis showed that patients whose tumor showed EphA1 up-regulation had a shorter survival time than those with reduced EphA1 expression (log-rank test, $\mathrm{P}=0.005)$ or no difference in expression ( $\mathrm{P}=0.003)$ (Fig. 4).

\section{Discussion}

Roles of the receptor tyrosine kinases (RTKs) in both normal physiology and oncogenesis have been well-established. The genes that encode Eph receptors, the largest subfamily of receptor tyrosine kinases, are primarily considered to be classical oncogenes, and overexpression of the EphA2 receptor has been well documented in many human cancers, including prostate cancer (20), colorectal cancer (21), gastric cancer (22), ovarian cancer (23), and endometrial cancer (24). Elevated EphA2 expression is correlated with disease stage, increased tumor metastasis, and poor patient survival. EphA2 plays a critical role in cancer progression. Overexpression of EphA4 correlates with liver metastasis in colorectal cancer (25), and promotes cancer cell growth in pancreatic ductal adenocarcinoma (26). However, the role of Eph receptors and Ephrin ligands in oncogenesis appears to be complex and remains ill-defined (27-29). There are increasing conflicting data regarding Eph receptor genes in different cancer types, especially in regard to the putative function of the genes that encode Eph receptors as oncogenes or tumor suppressor genes. The loss of expression of EphA3 in human T-cell line HPB-ALL is associated with hyper- 
Table IV. Relation between methylation status of EphA1 and clinicopathological parameters.

\begin{tabular}{|c|c|c|c|}
\hline \multirow[b]{2}{*}{ Variable } & \multicolumn{2}{|c|}{ Methylation status } & \multirow[b]{2}{*}{ P-value } \\
\hline & + & - & \\
\hline Case no. & 16 & 22 & \\
\hline \multicolumn{4}{|l|}{ Gender } \\
\hline Male & 12 & 17 & 1 \\
\hline Female & 4 & 5 & \\
\hline \multicolumn{4}{|l|}{ Age (years) } \\
\hline$\leq 50$ & 3 & 1 & 1 \\
\hline$>50$ & 13 & 21 & \\
\hline \multicolumn{4}{|l|}{ Differentiation } \\
\hline Moderately differentiated & 10 & 9 & 0.058 \\
\hline Poorly differentiated & 6 & 13 & \\
\hline \multicolumn{4}{|l|}{ Tumor size $(\mathrm{cm})$} \\
\hline$<5$ & 12 & 7 & 0.023 \\
\hline$\geq 5$ & 4 & 15 & \\
\hline \multicolumn{4}{|l|}{ Depth of wall invasion } \\
\hline Mucosa, submucosa & 1 & 0 & \\
\hline Muscularis propria & 5 & 5 & 0.712 \\
\hline Subserosa, serosa & 10 & 17 & \\
\hline \multicolumn{4}{|l|}{ Stage } \\
\hline I + II & 8 & 7 & 0.182 \\
\hline III + IV & 8 & 15 & \\
\hline \multicolumn{4}{|l|}{ Microscopic subtypes } \\
\hline Intestinal & 13 & 14 & 0.245 \\
\hline Diffuse & 2 & 6 & \\
\hline Other & 1 & 2 & \\
\hline \multicolumn{4}{|l|}{ Lymph node metastasis } \\
\hline Present & 10 & 17 & 0.471 \\
\hline Absent & 6 & 5 & \\
\hline
\end{tabular}

methylation of 5' upstream $\mathrm{CpG}$ island (30). Recent research findings regarding EphB2 and EphB4 in colorectal cancers have strengthened the hypothesis that Eph receptor gene can function as a tumor suppressor gene (25,31-33).

Wang et al have previously reported that down-regulation of the EphA7 receptor in colon cancer cell lines and colorectal cancer samples is secondary to hypermethylation of the $5^{\prime} \mathrm{CpG}$ island, and that down-regulation of the EphA7 is related to the differentiation of colorectal cancers (34). Investigation of expression of EphA7 in gastric carcinomas showed that EphA7 was decreased in all gastric cancer cell lines tested, but was markedly variable in gastric carcinoma specimens. Overexpression of EphA7 was more frequently observed in tumors from younger patients and patients with advanced stage disease, and no significant relation has been found between the expression of EphA7 and differentiation
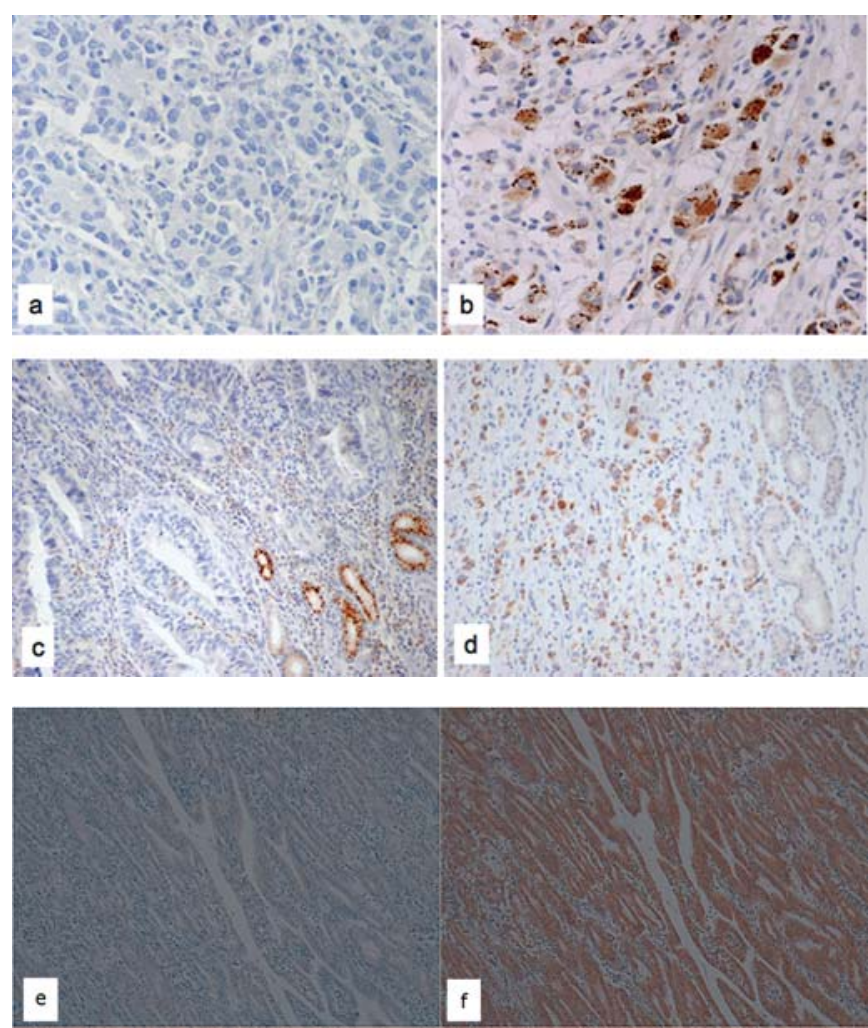

Figure 3. Immunohistochemical staining of EphA1 in gastric carcinomas. (a) Gastric carcinoma cells that had lost EphA1 protein expression. (b) Gastric carcinoma cells stained positive for EphA1 protein. (c) Down-regulation of EphA1 protein in gastric carcinoma. The normal gastric gland cells on the right show very strong brown staining, and the tumor cells show weak staining. (d) Up-regulation of EphA1 protein in gastric carcinoma. The normal gastric gland cells on the right show weak positive staining in comparison with the carcinoma cells. (e and f) Result of the adsorption test. The left panel (e) shows the adsorption of the antibody thereby validating the specificity of the antibody.

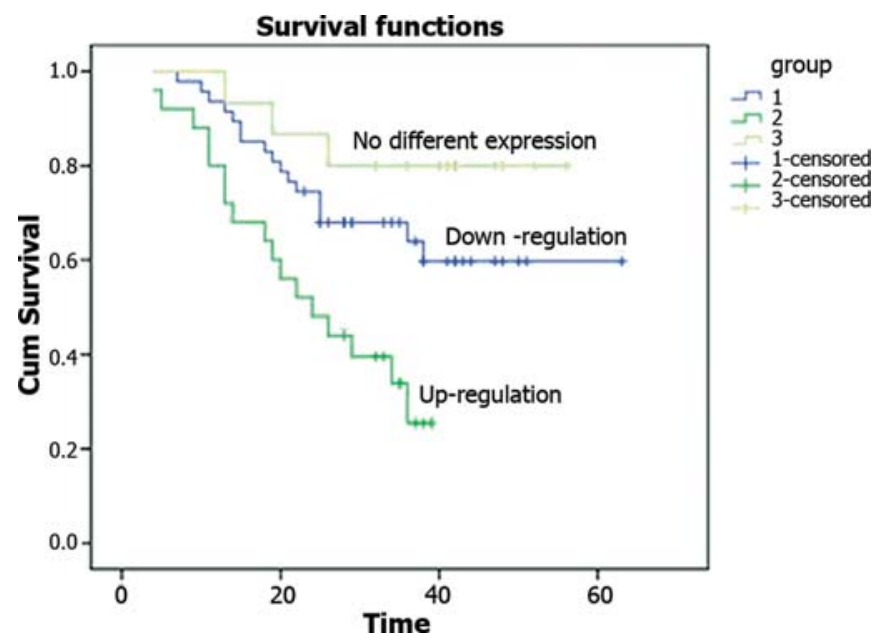

Figure 4. Kaplan-Meier plots of overall survival showing that the patients whose tumors exhibited EphA1 up-regulation had a shorter survival time (months) than those whose tumors exhibited EphA1 down-regulation $(\mathrm{P}=0.005)$ or no difference in expression $(\mathrm{P}=0.003)$. Lane 1 , patients whose tumors exhibited down-regulation of EphA1; lane 2, patients whose tumors exhibited up-regulation of EphA1; and lane 3, patients whose tumors exhibited no difference in expression. 
of gastric carcinoma (19). The above findings indicate that Eph receptors have unique functions that depend on the organ or cell lineage.

In the present study differential expression of EphA1 transcripts and protein was detected in a set of gastric carcinoma specimens. Consistent results for EphA1 transcript and protein expression level were found in 34 (61\%) out of 56 tumor samples that contained with both fresh and paraffin fixed tissues, and in the other $22(39 \%)$ the results were not consistent. This may partly be explained that by post-transcription regulation mechanisms. EphA2 has been demonstrated to contribute to tumor progression in several tumor types. Expression of EphA2 mutants lacking the cytoplasmic domain or carrying a point mutation in breast cancer cells resulted in decreased tumor volume and increased tumor apoptosis (35). siRNA knock-down of EphA2 expression in pancreatic cancer cells inhibits tumor growth and metastasis (36), and soluble EphA2-Fc receptor has been shown to effectively inhibit EphA2 receptor phosphorylation and tumor growth and metastasis (37). Our findings in this study indicated that EphA1 may have roles in the progression of gastric carcinoma. Gastric cancer cells that overexpressed EphA1 had greater invasive potential: 35 out of 39 (90\%) tumors that overexpressed EphA1 had invaded to the serosa or subserosa, whereas only $56(70 \%)$ of 80 tumors in patients with EphA1 down-regulation had invaded to the serosa or subserosa $(\mathrm{P}=0.069)$. Our data indicated that EphA1 may play different roles in progress of gastric carcinoma comparing with the roles in progress of colorectal carcinoma. The functions of EphA1 as an oncogene or a tumor suppressor depend on the organs where the cells located.

Expression of EphA1 transcripts and protein in gastric carcinoma was significantly associated with tumor metastasis $(\mathrm{P}=0.011$ and $\mathrm{P}=0.018$, respectively). The patients whose tumor exhibited up-regulation of EphA1 more commonly had lymph node metastasis. Gastric carcinoma patients whose tumor exhibited down-regulation of EphA1 transcripts had smaller tumors $(\mathrm{P}=0.05)$, however, the same finding was not observed in patients whose tumors exhibited down-regulation of EphA1 protein $(\mathrm{P}=0.268)$. Patients with up-regulation of EphA1 transcripts or protein had more advanced disease than those whose tumors exhibited down-regulation $(\mathrm{P}=0.001$ or $\mathrm{P}<0.001)$. No significant associations between expression of EphA1 transcripts and protein and sex, differentiation, or microscopic subtypes were observed.

There is a CG-rich region around EphA1 translation start site (Fig. 2), and the CG sites in this region can be divided into two groups, a 153 bp CG group (5'-CG-rich region) upstream of the translation start site and a $251 \mathrm{bp} \mathrm{CG}$ group (3'-CG-rich region) downstream of the translation start site. Methylation has been detected in the 5'-CG-rich region in colorectal cancer and corresponding normal samples, suggesting that this region is not involved in gene regulation. An inverse correlation has been found between methylation of $\mathrm{CpG}$ islands in the 3'-CG-rich region and EphA1 expression in colorectal cancers (18). We designed a set of methylation specific PCR (MSP) primers for 3'-CG-rich region to detect methylated and unmethylated EphA1 DNA, and we detected methylated EphA1 DNA in five colon cancer cell lines (17). In the present study we used MSP to analyze the methylation status of EphA1 in 38 fresh gastric carcinoma tissues (each including normal tissue and tumor tissue). Methylated EphA1 DNA was detected in most tumor tissues $(12 / 15,80 \%)$ that exhibited down-regulation of EphA1 transcript expression, suggesting epigenetic mechanism plays a role in expression of EphA1. Methylated EphA1 was detected in 3 of 18 samples in which there was no difference in expression between the normal tissues and tumor tissue, and in 1 of 5 samples in which EphA1 transcript expression was up-regulated. This can be partly interpreted as meaning that inflammation had developed in the tumor tissue. Another explanation is that the methylation status of gastric carcinoma cells is heterogeneous, and that small percentage of methylated cells detected by MSP could not alter the level of EphA1 expression in the tumor as a whole. EphA1 methylation in gastric carcinoma was associated with both tumor differentiation and tumor size $(\mathrm{P}=0.058$ and $\mathrm{P}=0.023$, respectively). No significant associations between EphA1 hypermethylation and other clinicopathological parameters were observed.

Follow-up information for 87 gastric carcinoma patients was available, and the association between EphA1 protein expression and overall survival rate was analyzed. The overall survival time of the patients with EphA1 up-regulation was shorter than that of the patients whose tumors exhibited down-regulation $(\mathrm{P}=0.005)$ or no difference in expression $(\mathrm{P}=0.003)$. Our data indicated that patients whose tumor exhibited overexpression of EphA1 had a poor prognosis. Briefly, the results of this study indicated that the EphA1 gene may play the role of an oncogene in gastric carcinoma, although intensive cell biological studies both in vitro and in vivo should be carried out to elucidate the mechanisms. The level of EphA1 expression may be useful as a potential prognostic marker in gastric carcinoma, and the EphA1 gene may serve as a novel target of therapy for gastric carcinoma.

\section{Acknowledgements}

This study was supported in part by National Basic Research Priorities Program 973 Project (2006, CB 705707) from the Ministry of Science and Technology of China, China Nanjing Medicine Science and Technology Research Project (No. 06Z37), National Natural Science Foundation of China (30970813, and 30930028), by the Ministry of Education, Culture, Science, Sports, and Technology of Japan (20014007), the Ministry of Health, Labour and Welfare of Japan (19-19), Research on International Cooperation in Medical Science and the Smoking Research Foundation.

\section{References}

1. Parkin DM, Bray F, Ferlay J and Pisani P: Global cancer statistics, 2002. CA Cancer J Clin 55: 74-108, 2005.

2. Chang MS, Uozaki H, Chong JM, et al: CpG island methylation status in gastric carcinoma with and without infection of EpsteinBarr virus. Clin Cancer Res 12: 2995-3002, 2006.

3. Wang LH, Kim SH, Lee JH, et al: Inactivation of SMAD4 tumor suppressor gene during gastric carcinoma progression. Clin Cancer Res 13: 102-110, 2007.

4. Cha EJ, Noh SJ, Kwon KS, et al: Expression of DBC1 and SIRT1 is associated with poor prognosis of gastric carcinoma. Clin Cancer Res 15: 4453-4459, 2009.

5. Kaizaki R, Yashiro M, Shinto O, et al: Expression of ER as oncogene in gastric carcinoma. Anticancer Res 29: 2189-2193, 2009 . 
6. Omori Y, Nakayama F, Li D, et al: Alternative lengthening of telomeres frequently occurs in mismatch repair system-deficient gastric carcinoma. Cancer Sci 100: 413-418, 2009.

7. Sakata M, Kitamura YH, Sakuraba K, et al: Methylation of HACE1 in gastric carcinoma. Anticancer Res 29: 2231-2233, 2009.

8. Toyokawa $\mathrm{T}$, Yashiro $\mathrm{M}$ and Hirakawa $\mathrm{K}$ : Co-expression of keratinocyte growth factor and $\mathrm{K}$-sam is an independent prognostic factor in gastric carcinoma. Oncol Rep 21: 875-880, 2009.

9. Tsamandas AC, Kardamakis D, Tsiamalos $\mathrm{P}$, et al: The potential role of Bcl-2 expression, apoptosis and cell proliferation (Ki-67 expression) in cases of gastric carcinoma and correlation with classic prognostic factors and patient outcome. Anticancer Res 29: 703-709, 2009.

10. Hirai H, Maru Y, Hagiwara K, Nishida J and Takaku F: A novel putative tyrosine kinase receptor encoded by the eph gene. Science 238: 1717-1720, 1987

11. Hafner C, Schmitz G, Meyer S, et al: Differential gene expression of Eph receptors and ephrins in benign human tissues and cancers. Clin Chem 50: 490-499, 2004.

12. Herath NI, Spanevello MD, Sabesan S, et al: Over-expression of Eph and ephrin genes in advanced ovarian cancer: ephrin gene expression correlates with shortened survival. BMC Cancer 6: 144, 2006.

13. Lin HS, Berry GJ, Fee WE Jr, Terris DJ and Sun Z: Identification of tyrosine kinases overexpressed in head and neck cancer. Arch Otolaryngol Head Neck Surg 130: 311-316, 2004.

14. Fox BP, Tabone CJ and Kandpal RP: Potential clinical relevance of Eph receptors and ephrin ligands expressed in prostate carcinoma cell lines. Biochem Biophys Res Commun 342: 1263-1272, 2006

15. Fox BP and Kandpal RP: Invasiveness of breast carcinoma cells and transcript profile: Eph receptors and ephrin ligands as molecular markers of potential diagnostic and prognostic application. Biochem Biophys Res Commun 318: 882-892, 2004.

16. Hafner C, Becker B, Landthaler M and Vogt T: Expression profile of Eph receptors and ephrin ligands in human skin and downregulation of EphA1 in non-melanoma skin cancer. Mod Pathol 19: 1369-1377, 2006.

17. Dong Y, Wang J, Sheng Z, et al: Downregulation of EphA1 in colorectal carcinomas correlates with invasion and metastasis. Mod Pathol 22: 151-160, 2009.

18. Herath NI, Doecke J, Spanevello MD, Leggett BA and Boyd AW: Epigenetic silencing of EphA1 expression in colorectal cancer is correlated with poor survival. Br J Cancer 100: 1095-1102, 2009.

19. Wang J, Li G, Ma H, et al: Differential expression of EphA7 receptor tyrosine kinase in gastric carcinoma. Hum Pathol 38: 1649-1656, 2007.

20. Walker-Daniels J, Coffman K, Azimi M, et al: Overexpression of the EphA2 tyrosine kinase in prostate cancer. Prostate 41: 275-280, 1999.

21. Kataoka H, Igarashi H, Kanamori M, et al: Correlation of EPHA2 overexpression with high microvessel count in human primary colorectal cancer. Cancer Sci 95: 136-141, 2004.
22. Nakamura R, Kataoka H, Sato N, et al: EPHA2/EFNA1 expression in human gastric cancer. Cancer Sci 96: 42-47, 2005.

23. Lin YG, Han LY, Kamat AA, et al: EphA2 overexpression is associated with angiogenesis in ovarian cancer. Cancer 109: 332-340, 2007.

24. Kamat AA, Coffey D, Merritt WM, et al: EphA2 overexpression is associated with lack of hormone receptor expression and poor outcome in endometrial cancer. Cancer 115: 2684-2692, 2009.

25. Oshima T, Akaike M, Yoshihara K, et al: Overexpression of EphA4 gene and reduced expression of EphB2 gene correlates with liver metastasis in colorectal cancer. Int J Oncol 33: 573-577, 2008

26. Iiizumi M, Hosokawa M, Takehara A, et al: EphA4 receptor, overexpressed in pancreatic ductal adenocarcinoma, promotes cancer cell growth. Cancer Sci 97: 1211-1216, 2006.

27. Surawska H, Ma PC and Salgia R: The role of ephrins and Eph receptors in cancer. Cytokine Growth Factor Rev 15: 419-433, 2004.

28. Chen J, Zhuang G, Frieden L and Debinski W: Eph receptors and Ephrins in cancer: common themes and controversies. Cancer Res 68: 10031-10033, 2008.

29. Vaught D, Brantley-Sieders DM and Chen J: Eph receptors in breast cancer: roles in tumor promotion and tumor suppression. Breast Cancer Res 10: 217, 2008.

30. Dottori M, Down M, Huttmann A, Fitzpatrick DR and Boyd AW: Cloning and characterization of EphA3 (Hek) gene promoter: DNA methylation regulates expression in hematopoietic tumor cells. Blood 94: 2477-2486, 1999.

31. Batlle E, Bacani J, Begthel H, et al: EphB receptor activity suppresses colorectal cancer progression. Nature 435: 1126-1130, 2005.

32. Clevers $\mathrm{H}$ and Batlle $\mathrm{E}$ : EphB/EphrinB receptors and Wnt signaling in colorectal cancer. Cancer Res 66: 2-5, 2006.

33. Cortina C, Palomo-Ponce S, Iglesias M, et al: EphB-ephrin-B interactions suppress colorectal cancer progression by compartmentalizing tumor cells. Nat Genet 39: 1376-1383, 2007.

34. Wang J, Kataoka H, Suzuki M, et al: Downregulation of EphA7 by hypermethylation in colorectal cancer. Oncogene 24: 5637-5647, 2005.

35. Fang WB, Brantley-Sieders DM, Parker MA, Reith AD and Chen $\mathrm{J}$ : A kinase-dependent role for EphA2 receptor in promoting tumor growth and metastasis. Oncogene 24: 7859$7868,2005$.

36. Duxbury MS, Ito H, Zinner MJ, Ashley SW and Whang EE: Ligation of EphA2 by Ephrin A1-Fc inhibits pancreatic adenocarcinoma cellular invasiveness. Biochem Biophys Res Commun 320: 1096-1102, 2004.

37. Brantley DM, Cheng N, Thompson EJ, et al: Soluble Eph A receptors inhibit tumor angiogenesis and progression in vivo. Oncogene 21: 7011-7026, 2002. 